\author{
Dariusz MILEWSKI \\ https://orcid.org/0000-0002-3255-7685 \\ Instytut Historii Uniwersytetu Kardynała Stefana Wyszyńskiego w Warszawie
}

\title{
Listy senatorów koronnych do margrabiego Jerzego Fryderyka i nadradców pruskich w okresie trzeciego bezkrólewia (1586-1587)
}

\begin{abstract}
Zarys treści: W berlińskim Geheimes Staatsarchiv Preußischer Kulturbesitz znajdują się oryginalne listy wysyłane przez Polaków do władz Prus Książęcych, a wśród nich osiem listów senatorów koronnych pisanych do margrabiego Jerzego Fryderyka oraz nadradców pruskich w czasie trzeciego bezkrólewia (1586-1587). Przedmiotem artykułu jest edycja wspomnianych listów oraz omówienie ich na tle stosunków polsko-pruskich.
\end{abstract}

\begin{abstract}
There are in the Geheimes Staatsarchiv Preußischer Kulturbesitz in Berlin original letters written by Poles to the government of the Duchy of Prussia; eight of them were written by Crown senators to Margrave George Frederick and Prussian councillors-general during the third interregnum (1586-1587). The subject of the article is the edition of the abovementioned letters and their presentation in the context of Polish-Prussian relations.
\end{abstract}

Słowa kluczowe: senatorzy koronni, Prusy Książęce, korespondencja

Keywords: Crown senators, Duchy of Prussia, correspondence

Prusy Książęce odgrywały początkowo niewielką rolę w polityce Rzeczypospolitej, o czym decydowała różnica w potencjale ludnościowym i obszarowym między suzerenem a lennikiem. Także zerwanie przez Hohenzollernów kontaktów z Cesarstwem w wyniku sekularyzacji zakonu krzyżackiego w 1525 r. skazywało księcia Albrechta na ścisłą współpracę ze swymi jagiellońskimi krewnymi: Zygmuntem Starym i Zygmuntem Augustem. Niemniej, podtrzymywanie związków z bocznymi liniami Hohenzollernów, dzierżącymi różne włości w Rzeszy - początkowo z margrabiami Ansbachu, później również z elektorami brandenburskimi - pozwoliło Prusom Książęcym wyjść z izolacji. Znaczenie księstwa wzrastało również w dobie kryzysów bądź wojen toczonych przez państwo polsko-litewskie w strefie bałtyckiej. Widać to wyraźnie w okresie zaangażowania się Zygmunta Augusta w zdobycie Inflant, kiedy to książę Albrecht Hohenzollern do spółki z bratem Wilhelmem, arcybiskupem ryskim, inspirowali w dużym stopniu poczynania króla polskiego. Prusy pojawiły się znów na arenie politycznej w czasie sporu i wojny Stefana Batorego z Gdańskiem w 1577 r. To właśnie odmowa ze strony Prusaków wsparcia finansowego króla i ich jawne sympatie okazywane gdańszczanom stały się jednym z motywów powierzenia kurateli nad chorym umysłowo księciem Albrechtem II jego kuzynowi, margrabiemu Ansbachu Jerzemu Fryderykowi. $\mathrm{Na}$ nic zdały się wówczas spóźnione protesty Prusaków, słusznie obawiających się słynącego z twardej ręki margrabiego. Stefan Batory potrzebował sprawnego zarządcy w Prusach, który byłby mu wdzięczny za powierzenie władzy i gotów za tę przysługę sowicie zapłacić. A ponieważ król potrzebował pilnie gotówki na wojnę moskiewską - Iwan IV najechał bowiem w 1577 r. Inflanty, korzystając z zaabsorbowania króla sprawami gdańskimi - a Jerzy Fryderyk oferował 200 tys. zł oraz 500 żołnierzy, tedy targu dobito. 
Warto też wspomnieć, że niedarzący sympatią Habsburgów margrabia ansbachski był także z tego tytułu cennym sojusznikiem w Rzeszy króla polskiego - który wszak wygrał wyścig do korony polskiej z cesarzem Maksymilianem II, a i na terenie Siedmiogrodu i Węgier rywalizował z wiedeńską dynastią ${ }^{1}$.

Wspomniane wyżej okoliczności sprawiły, że Jerzy Fryderyk mógł czuć się komfortowo jako kurator w Prusach Książęcych w okresie panowania Stefana Batorego. Bezkrólewie oznaczało niepewny okres tak dla margrabiego, jak i samych Prus Książęcych. Ewentualna elekcja Habsburga - do której tak familia cesarska, jak i jej adherenci w Rzeczypospolitej pilnie się przygotowywali ${ }^{2}$ - była dla margrabiego wyzwaniem w kontekście jego nie najlepszych stosunków z tą dynastią. Także senatorowie polscy i litewscy, na których barkach spoczęło kierowanie państwem w czasie bezkrólewia, musieli zabezpieczyć Rzeczpospolitą od wszelkich możliwych zagrożeń. Utrzymanie spokoju wewnętrznego i zewnętrznego było priorytetem trudnym do osiągnięcia, zwłaszcza w kontekście ostrej walki politycznej, w jakiej pogrążyła się Rzeczpospolita w ostatnich latach rządów Stefana Batorego. Szło oczywiście o spór króla - wspieranego przez kanclerza i hetmana wielkiego koronnego Jana Zamoyskiego - z rodem Zborowskich i ich stronnikami. Pomimo starań prymasa i zarazem interreksa Stanisława Karnkowskiego, dążącego do wyciszenia sporów w interesie dobra wspólnego, ostra rywalizacja kanclerza i Zborowskich zdominowała trzecie bezkrólewie i zaowocowała podwójną elekcją Zygmunta Wazy (19 VIII 1587) i arcyksięcia Maksymiliana Habsburga (22 VIII 1587)². W ślad za tym doszło do wojny, w czasie której Habsburg bezskutecznie usiłował zdobyć Kraków, a następnie został pokonany w bitwie pod Byczyną 24 I 1588 i trafił do niewoli kanclerza wielkiego koronnego ${ }^{4}$.

Wśród tak burzliwych dziejów trzeciego bezkrólewia sprawą interesującą będzie przyjrzenie się postawie senatorów polskich wobec Prus Książęcych. Jakkolwiek zarówno rola tego państwa, jak i władającego nim margrabiego ansbachskiego Jerzego Fryderyka była drugorzędna w porównaniu do znaczenia rządzonego przez Habsburgów Cesarstwa czy nawet Moskwy, to jednak warto będzie przyjrzeć się kontaktom polsko-pruskim nawiązywanym w tym trudnym okresie ${ }^{5}$.

Przedmiotem naszej analizy będzie korespondencja kierowana przez senatorów polskich do władz Prus Książęcych, a więc margrabiego Jerzego Fryderyka oraz reprezentującego go w Królewcu kolegium nadradców (zwanych przez Polaków regentami pruskimi) ${ }^{6}$. W skład czteroosobowego kolegium wchodzili ochmistrz (Hofmeister), naczelny marszałek (Obermarschall), nadburgrabia (Oberburgraf) i kanclerz (Kanzler) $)^{7}$. Interesować nas będą listy wysyłane od śmierci Stefana Batorego w grudniu $1586 \mathrm{r}$. do chwili koronacji Zygmunta III rok później. Jakkolwiek bowiem królewicz szwedzki został wybrany w sierpniu 1587 r., to jednak dopiero jego przyjazd do Krakowa, koronacja 27 XII 1587 i odprawienie sejmu koronacyjnego zakończyły faktycznie okres bezkrólewia.

\footnotetext{
${ }^{1}$ AGAD, Zbiór dokumentów pergaminowych, sygn. 6922, Zobowiązanie Jerzego Fryderyka do wpłacenia 200 tys. zł królowi, Ansbach, 23 XII 1577; R. Heidenstein, Dzieje Polski od śmierci Zygmunta Augusta do roku 1594. Ksiag XII, thum. M. Gliszczyński, oprac. J. Byliński, W. Kaczorowski, Opole 2015, s. 254, 264 n.; tenże, Pamiętniki wojny moskiewskiej w 6 księgach, thum. J. Czubek, Warszawa 2017, s. 27; zob. B. Wachowiak, A. Kamieński, Dzieje Brandenburgii-Prus na progu czasów nowożytnych (1500-1701), Poznań 2001, s. 223-226; H. Lulewicz, Gniewów o unię ciąg dalszy. Stosunki polsko-litewskie w latach 1569-1588, Warszawa 2002, s. 314.

2 Ostatnio na ten temat zob. A. Barwicka-Makula, Od wrogości do przyjaźni. Habsburgowie austriaccy wobec Polski w latach 1587-1592, Katowice 2019, s. 65-110.

3 J. Dzięgielewski, Sejmy elekcyjne, elektorzy, elekcje 1573-1674, Pułtusk 2003, s. 96-101; A. Pieńkowska, Zjazdy i sejmy z okresu bezkrólewia po śmierci Stefana Batorego, Pułtusk 2010.

${ }^{4}$ M. Plewczyński, Wojny i wojskowość polska w XVI wieku, t. 3: Lata 1576-1599, Zabrze-Tarnowskie Góry 2013, s. 211-258.

5 Jerzy Fryderyk oprócz Ansbachu i Bayreuth posiadał też księstwa na Śląsku, przede wszystkim karniowskie i okresowo opolsko-raciborskie, a później żagańskie. Był z tego tytułu lennikiem cesarza jako króla Czech; szerzej o postaci i polityce margrabiego zob. J. Petersohn, Markgraf Georg Friedrich von Brandenburg-Ansbach und Bayreuth als Herzog in Preußen 1578-1603, Bonn 1959.

${ }^{6} \mathrm{Na}$ znaczenie tego typu dokumentacji dla badań historycznych w kontekście stosunków z Habsburgami zwróciła uwagę E. Dubas-Urwanowicz, Korespondencja oficjalna i prywatna w kontaktach między Rzeczapospolita a Cesarstwem. Polonica w Haus-, Hof- und Staatsarchiv w Wiedniu z lat 1562-1578, Przegl. Hist., 83, 1992, nr 3, s. 497 n.

7 J. Małłek, Ustawa o rzadzie (Regimentsnottel) Prus Ksiązęcych z roku 1542. Studium z dziejów przemian społecznych i politycznych w lennie pruskim, Toruń 1967, s. 163-166.
} 
Listy, o których mowa, przechowywane są w zasobach berlińskiego Geheimes Staatsarchiv Preußischer Kulturbesitz, w zespołach Herzogliches Briefarchiv i Ostpreußische Folianten. Pierwszy z nich zawiera korespondencję książąt pruskich począwszy od 1525 r. i dzieli się na kilka działów. Wśród nich dział B jest poświęcony Polsce, przy czym B1 obejmuje korespondencję z królami i członkami rodzin królewskich, B2 zaś zawiera listy wymieniane z dygnitarzami. W ramach działów listy przechowywane są w osobnych kasetach (Kasten), w nie zawsze sygnowanych obwolutach ${ }^{8}$. Oryginalne listy senatorów polskich do władz pruskich z okresu trzeciego bezkrólewia znajdują się w Herzogliches Briefarchiv B2, Kasten 407. Interesujący nas materiał źródłowy obejmuje siedem listów napisanych w okresie od 17 XII 1586 do 1 I 1588 przez pięciu senatorów indywidualnie i jeden list sygnowany przez sześciu senatorów. Oryginalnych listów senatorskich w tym zespole archiwalnym jest oczywiście więcej, jednak pochodzą one z innych lat ${ }^{9}$. Oprócz nich możemy znaleźć również kopie listów. Sygnatariuszami listów z czasów trzeciego bezkrólewia byli: Jan Zamoyski kanclerz i hetman wielki koronny (1 list), Wojciech Baranowski ${ }^{10}$ podkanclerzy koronny i biskup przemyski (3 listy), Stanisław Górka ${ }^{11}$ wojewoda poznański (1 list), Grzegorz Zieliński ${ }^{12}$ wojewoda płocki (1 list) i Maciej Żaliński ${ }^{13}$ kasztelan gdański (1 list). Odbiorcami listów byli margrabia ansbachski Jerzy Fryderyk Hohenzollern (2 listy) oraz nadradcy pruscy (6 listów).

$\mathrm{Z}$ kolei w zespole Ostpreußische Folianten przechowywana jest m.in. korespondencja władz pruskich z królami polskimi, dygnitarzami oraz mieszkańcami Rzeczypospolitej, załatwiającymi swoje interesy w Prusach Książęcych ${ }^{14}$. Pod sygnaturą 113 znajdziemy zarówno kopie listów z HBA B2 407, jak i innych listów, w tym wysyłanych do senatorów polskich przez Prusaków. Pozwalają one poznać kontekst oryginalnej korespondencji.

We wspomnianym okresie pisywali z władzami pruskimi również starostowie pograniczni. Aktywnym korespondentem był starosta ciechanowski Krzysztof Niszczycki, zasłużony rotmistrz i zwolennik kandydatury wazowskiej. Między styczniem a majem $1587 \mathrm{r}$. wysłał on trzy listy do nadradców pruskich ${ }^{15}$. Jako że godności senatorskie osiągnął jednak niemal 20 lat później (kasztelanię raciąską, a potem województwo bełskie), pomijamy go w niniejszych rozważaniach. Podobnie pominiemy starostę rajgrodzkiego i augustowskiego Marcina Dulskiego, który wysłał jeden list do nadradców pruskich w lutym 1587 r. ${ }^{16}$

${ }^{8}$ Geheimes Staatsarchiv Preußischen Kulturbesitz [dalej: GStA PK], XX Hauptabteilung - Staatsarchiv Königsberg [dalej: XX HA], Rep. Herzogliches Briefarchiv [dalej: HBA]; S. Hartmann, Das Geheime Staatsarchiv Preußischer Kulturbesitz in Berlin und Archiv der Herzöge in Preußen (Das Herzogliche Briefarchiv und seine Regestierung), „Mrągowskie Studia Humanistyczne", 6-7, 2004-2005, s. 350-352. Dziękuję Panu prof. Sławomirowi Augusiewiczowi za pomoc okazaną w rozeznaniu się w strukturze berlińskiego archiwum.

9 Sygnatura HBA B2 Kasten 407 obejmuje listy z lat 1586-1588. Kasten 406 obejmuje korespondencję z 1585 r., za to Kasten 408 - z lat 1589-1591.

${ }^{10}$ Wojciech Baranowski po nominacji na biskupstwo płockie w 1590 r. zrezygnował z podkanclerstwa. Był następnie biskupem kujawskim (1607) i wreszcie arcybiskupem gnieźnieńskim (1608); zob. A. Strzelecki, Baranowski Wojciech (1548-1615), w: PSB, t. 1, Kraków 1935, s. 286-289.

11 Stanisław Górka, wojewoda poznański, początkowo czynny zwolennik Stefana Batorego, później w opozycji do króla; w okresie trzeciego bezkrólewia jeden z czołowych adherentów arcyksięcia Maksymiliana; zob. K. Lepszy, Górka Stanisław (1538-1592), w: PSB, t. 8, Wrocław 1959-1960, s. 416-421.

12 Grzegorz Zieliński, zwolennik Stefana Batorego, nagrodzony już w 1576 r. kasztelanią płocką i starostwami zakroczymskim i mławskim, w 1582 r. awansowany na wojewodę płockiego; w 1587 r. zwolennik kandydatury Zygmunta Wazy; zob. R. Zieliński, Wojewoda płocki Grzegorz Zieliński († 1599), „Notatki Płockie”, 2, 1957, nr 6, s. 2-8.

${ }^{13}$ Maciej Żaliński, od 1574 r. kasztelan gdański, w dobie drugiego bezkrólewia zwolennik cesarza Maksymiliana II Habsburga; zob. Urzędnicy Prus Królewskich XV-XVIII wieku. Spisy, oprac. K. Mikulski, Wrocław 1990, poz. 424, s. 90; W. Szczuczko, Żaliński Maciej, w: Słownik biograficzny Pomorza Nadwiślańskiego, t. 4, red. Z. Nowak, Gdańsk 1997, s. 538 n.

${ }^{14}$ GStA PK, XX HA, Ostpreußische Folianten [dalej: OsF]. Wykaz korespondencji prusko-warmińskiej z obu zespołów dla okresu bliskiego niniejszej pracy zestawił S. Hartmann, Die Herzöge Albrecht Friedrich und Georg Friedrich von Preußen und das Bistum Ermland (1568-1618). Regesten aus dem Herzoglichen Briefarchiv und den Ostpreußen Folianten mit ergänzenden Schriftstücken bis 1699, Köln 1994.

15 GStA PK, XX HA, HBA B2 407, K. Niszczycki do nadradców pruskich, Ciechanów, 8 I, 12 IV i 2 V 1587. O Krzysztofie Niszczyckim zob. H. Kotarski, Niszczycki Krzysztof (ok. 1540-1617), w: PSB, t. 23, Wrocław 1978, s. 135 n.

16 GStA PK, XX HA, HBA B2 407, M. Dulski do nadradców pruskich, Rajgród, [28 II] 1587. O Marcinie Dulskim zob. K. Niesiecki, Herbarz polski, t. 3, wyd. J.N. Bobrowicz, Lipsk 1839, s. 434. Kopie listów wysłanych przez nadradców 
Zawężenie tematu pracy do listów senatorów koronnych z krótkiego okresu domaga się wyjaśnienia. Bogaty zasób archiwum berlińskiego dostarcza wielu cennych materiałów do dziejów polskich. Intencją naszą było przedstawienie oryginalnej korespondencji strony polskiej z burzliwego czasu trzeciego bezkrólewia. O wyborze tego właśnie okresu zdecydowała jego krótkość, a zarazem intensywność wydarzeń politycznych. Waskie ramy chronologiczne pozwoliły na przedstawienie pełnej oryginalnej korespondencji. Zdecydowano się przy tym na edycję listów senatorów z uwagi na znaczenie senatu w życiu publicznym - wzrastające $\mathrm{w}$ dobie bezkrólewia ${ }^{17}$. Ciekawym było przyjrzenie się, kto i w jakich sprawach pisywał do władz pruskich. Nietrudno przy tym zauważyć, że korespondowali głównie ministrowie - kanclerz i podkanclerzy koronni - oraz senatorowie związani z pograniczem pruskim czy szerzej niemieckim (kasztelan gdański, wojewodowie płocki i poznański). Korespondencję litewską pominięto tak z racji specyficznej polityki Litwy wobec elekcji 1587 r., jak i z uwagi na formalnoprawne powiązania Prus Książęcych właśnie z Koroną ${ }^{18}$.

Pierwszą i najważniejszą sprawą, jaka pojawia się w listach polskich senatorów, jest śmierć króla Stefana Batorego. Jak wiemy, była ona tak niespodziewana, że najbliższego współpracownika króla kanclerza i hetmana Jana Zamoyskiego - zastała daleko od monarchy. Niemniej kanclerz poczuł się w obowiązku powiadomić nadradców pruskich o zgonie władcy polskiego, co uczynił, pisząc do nich z Bełza 17 XII 1586 (zob. aneks, nr 1). Jest to zarazem pierwsze pismo senatora polskiego do władz pruskich w okresie trzeciego bezkrólewia, jakie znajdujemy w omawianych zespołach archiwalnych. Wytrawny polityk nie ograniczył się bynajmniej do zawiadomienia o śmierci króla, ale podjął też kroki mające zjednać sobie Prusaków dla własnych koncepcji. Zmierzały one do niedopuszczenia do elekcji Habsburga i objęcia tronu albo przez samego kanclerza, albo przez któregoś z Batorych. W tym celu wysłał do Królewca sekretarza Reinholda Heidensteina, zlecając mu przeprowadzenie rozmów z księciem i nadradcami oraz prosząc o okazanie mu pełnego zaufania („ei igitur, ut omnibus de rebus, quas meo nomine illis proponet, summam fidem, non secus quam si ipse coram cum iis agerem, adhibeant") ${ }^{19}$. Niestety nie znamy szczegółów misji, które kanclerz powierzył nie papierowi, ale zaufanemu sekretarzowi. Nadradcy odpowiedzieli Janowi Zamoyskiemu 6 I 1587, deklarując chęć utrzymania pokoju i życząc zgodnego wyboru króla ${ }^{20}$.

Jerzy Fryderyk, dowiedziawszy się od nadradców o śmierci króla, wysłał listy z kondolencjami do królowej Anny oraz do Jana Zamoyskiego. Pisząc do kanclerza, margrabia życzył zgodnej elekcji i prosił o zapobieżenie ewentualnym zaburzeniom w Prusach ${ }^{21}$.

Nadradców pruskich poinformował oficjalnie o śmierci królewskiej podkanclerzy koronny i zarazem biskup przemyski Wojciech Baranowski listem z 21 XII 1586 (zob. aneks, nr 2). Ksiądz podkanclerzy pominął kwestie polityczne związane z rozpoczynającym się bezkrólewiem. Skupił się na opisie choroby królewskiej oraz wyrażeniu żalu z powodu odejścia Stefana Batorego ${ }^{22}$. Wojciech Baranowski

pruskich do K. Niszczyckiego i M. Dulskiego wraz z odpowiedziami (marzec - maj 1587 r.) zob. GStA PK, XX HA, OsF 113, k. 302-309, 317-319v.

17 W zamyśle autora niniejsza praca ma stanowić wkład do badań nad dziejami senatu koronnego, dlatego też konsekwentnie pominięto listy niesenatorskie.

18 Oprócz wspomnianej wyżej pracy H. Lulewicza, Gniewów o unię ciąg dalszy, politykę Litwinów w tym okresie omówił ostatnio K. Żojdź, Wszyscy ludzie króla. Zygmunt III Waza i jego stronnicy w Wielkim Księstwie Litewskim w pierwszych dekadach XVII wieku, Torun 2019, s. 67-74.

19 GStA PK, XX HA, HBA B2 407 (kopia: OsF 113, k. 49v-50), J. Zamoyski do nadradców pruskich, Bełz, 17 XII 1586.

${ }^{20}$ GStA PK, XX HA, OsF 113, k. 50-50v, Nadradcy pruscy do J. Zamoyskiego, Królewiec, 6 I 1587. Sam R. Heidenstein wspomina tylko enigmatycznie o „,iągłych” kontaktach kanclerza z księciem pruskim (zapewne z margrabią Jerzym Fryderykiem), które nie przyniosły konkretnych rezultatów; tenże, Dzieje Polski, s. 522.

${ }^{21}$ GStA PK, XX HA, OsF 113, k. 96-96v, Jerzy Fryderyk do J. Zamoyskiego, Ansbach, 25 XII 1586/4 I 1587 (kopia - list wydany w: Archiwum Jana Zamoyskiego, kanclerza i hetmana wielkiego koronnego, t. 4: 1585-1588, wyd. K. Lepszy, Kraków 1948, nr 1195, s. 99 n.); tamże, k. 95-96, tenże do Anny Jagiellonki, Ansbach, 25 XII 1586/4 I 1587 (kopia).

22 GStA PK, XX HA, HBA B2 407, W. Baranowski do nadradców pruskich, Grodno, 21 XII 1586. Pod tą samą sygnaturą znajduje się kopia tego listu; inna kopia: OsF 113, k. 2v-3. 
wysławiał zmarłego króla, dodając zarazem kilka szczegółów dotyczących jego śmierci ${ }^{23}$. Pisząc do nadradców, podkanclerzy odpowiadał na zapytanie z Królewca, dokąd doszły wieści o zgonie króla ${ }^{24}$.

Ten sam senator podjął wszak sprawy polityczne niecały miesiąc później, zwracając się do nadradców pruskich w ostatnim dniu obrad zjazdu senatorów litewskich (zob. aneks, nr 3). Trzynastu senatorów Wielkiego Księstwa zjechało się do Grodna 6 I 1587, by przy ciele monarchy zastanowić się nad sprawami państwa. Postanowiono wtedy m.in. zwołać sejmiki na Litwie, zwrócić się do Koroniarzy o szybkie zwołanie konwokacji, za to do cara Fiodora wysłano oficjalne zawiadomienie o zgonie króla wraz z propozycją przedłużenia rozejmu ${ }^{25}$. Obecny w Grodnie podkanclerzy koronny odpowiedział nadradcom pruskim na ich list z 21 grudnia, powiadamiając w skrócie o wyniku obrad, skupiając się na gwarancji bezpieczeństwa granicy prusko-litewskiej. Poinformował też Prusaków o zwołanej przez prymasa Stanisława Karnkowskiego konwokacji, mającej rozpocząć się 2 lutego w Warszawie ${ }^{26}$. W związku z tym wzywał do zachowania spokoju oraz zachęcał do przysłania posłów pruskich na konwokację, aby tam omówić z senatorami sprawy Księstwa Pruskiego ${ }^{27}$.

Nadradcy pruscy rzeczywiście nie tracili czasu i już na początku stycznia wysłali do Polski sekretarza książęcego Michaela Giesego, o czym powiadomili tak królową, jak i senatorów. Szczegóły misji sprecyzowano w instrukcji dopiero 21 stycznia. Zlecono posłowi zapewnić Polaków o wierności Prus i przeprosić za spóźnione kondolencje od margrabiego, spowodowane odległością Ansbachu od Grodna; zapewniano o woli utrzymania pokoju i proszono o potwierdzenie praw księstwa oraz samego margrabiego. W pierwszej kolejności apelowano o zapewnienie spokoju na granicy mazowieckiej i bezpieczeństwa nawigacji morskiej ${ }^{28}$.

Posłowie pruscy przybyli też na zjazd konwokacyjny i 6 lutego otrzymali posłuchanie u królowej Anny. Przewodzący legacji kanclerz pruski Friedrich Scharff wygłosił wobec królowej mowę kondolencyjną, za którą dziękował właśnie podkanclerzy Wojciech Baranowski. Posłowie mieli też okazję uczestniczyć w posiedzeniu senatu 7 lutego. Szczegółowe propozycje margrabiego przedstawił senatorom Michael Giese. Powtórzył zapewnienia wierności i prośbę o potwierdzenie praw, jak też odrzucił wszelkie „kalumnie” pod adresem margrabiego. Co najważniejsze, prosił o przyznanie margrabiemu jako kuratorowi księcia pruskiego - prawa głosu w elekcji nowego króla ${ }^{29}$. Żądając tego, Prusacy mogli odwoływać się do czternastego punktu traktatu krakowskiego z 8 IV 1525, dającego księciu pierwsze i najbliższe miejsce przy królu na sejmach i zjazdach ${ }^{30}$. Jednak już od samego początku zaczęto odsuwać

23 „Excessit ex hac vita Rex noster, non eo quidem die, de quo Dominationes Vestrae acceperant, sed postero, id est duodecimo decembris post occasum solis, ante primam horam noctis, magno nostro dolore, magno non tantum nostrae, sed universae Christianae Reipublicae incomodo"; GStA PK, XX HA, HBA B2 407, W. Baranowski do nadradców pruskich, Grodno, 21 XII 1586. W dalszym ciągu listu podkanclerzy opisuje końcowe objawy choroby króla.

${ }^{24}$ GStA PK, XX HA, OsF 113, k. 2-2v, M. Giese do W. Baranowskiego, Królewiec, po 11 XII 1586.

${ }^{25}$ A. Pieńkowska, Zjazdy i sejmy, s. 92 n.; zob. Uniwersat senatorów litewskich do szlachty o zwołaniu sejmików powiatowych i zjazdu stanów, Grodno, 8 I 1587, w: Akta zjazdów Wielkiego Księstwa Litewskiego, t. 1: Okresy bezkrólewi, oprac. H. Lulewicz, Warszawa 2006, nr 69, s. 195-197.

26 Prymas zwołał konwokację uniwersałem z 20 XII 1586; A. Pieńkowska, Zjazdy i sejmy, s. 99 n.

${ }^{27}$ GStA PK, XX HA, OsF 113, k. 6v-8, Nadradcy pruscy do W. Baranowskiego, Królewiec, 21 XII 1586; GStA PK, XX HA, HBA B2 407, W. Baranowski do nadradców pruskich, Grodno, 12 I 1587. Podobny w treści list wysłał kasztelan wileński i kanclerz wielki litewski: GStA PK, XX HA, OsF 113, k. 10-11, E. Wołłowicz do nadradców pruskich, Grodno, 12 I 1587; tamże, k. 115v-116v, nadradcy pruscy do E. Wołłowicza, Królewiec, 13/23 I 1587.

${ }^{28}$ GStA PK, XX HA, OsF 113, k. 104v, Nadradcy pruscy do Anny Jagiellonki, Królewiec, 1/11 I 1587; tamże, k. 105, ciż do senatorów, Królewiec, 1/11 I 1587; tamże, k. 105v, ciż do wojewodów i kasztelanów, Królewiec, 1/11 I 1587; tamże, k. 106-108, Instrukcja dla M. Giesego, [Królewiec], 21 I 1587.

${ }^{29}$ GStA PK, XX HA, OsF 113, k. 132-135, Mowa F. Scharffa, 6 II 1587; tamże, k. 135v-136, Odpowiedź na nią W. Baranowskiego, 6 II 1587; tamże, k. 136-137, M. Giese do senatorów polskich, Warszawa, 7 II 1587; Diariusze sejmowe r. 1587. Sejmy konwokacyjny i elekcyjny, wyd. A. Sokołowski, Scriptores Rerum Polonicarum, t. 11, Kraków 1887, s. 15 n.; A. Pieńkowska, Zjazdy i sejmy, s. 198.

30 „Item quod princeps ex Prussia primum et proximum locum in consiliis terrarum, comitiis et publicis conventibus apud regiam majestatem habere debet” - pokój krakowski, Kraków, 8 IV 1525, w: M. Bogucka, K. Zernack, Sekularyzacja Zakonu Krzyżackiego w Prusach. Hołd pruski 1525 roku, Warszawa 1998, s. 30 n. 
księcia Albrechta od prac senatu i odmówiono mu udziału w elekcji królewskiej Zygmunta Augusta i kolejnych władców. Potwierdziły to decyzje Zygmunta Starego w 1532 r. i jego syna w 1552 r. ${ }^{31}$ Ponad pół wieku później senatorzy koronni nadal trwali na tym samym stanowisku. Senat udzielił odpowiedzi na poselstwo pruskie 7 marca. Przyjęto zapewnienia o wierności Jerzego Fryderyka i deklarowano zabezpieczenie granicy pruskiej. Odrzucono jednak prośbę o dopuszczenie do udziału w elekcji ${ }^{32}$. Spotkało się to $\mathrm{z}$ natychmiastowym protestem jego wysłanników ${ }^{33}$.

Z okresu między konwokacją a elekcją znamy jeden list wojewody płockiego do nadradców pruskich (zob. aneks, nr 4). Nie przynosi on rewelacji politycznych. Jest odpowiedzią na list nadradców wysłany w marcu tak do wojewody, jak i starostów Krzysztofa Niszczyckiego i Marcina Dulskiego ${ }^{34}$. Nadradcy przypominali wojewodzie i pogranicznym starostom mazowieckim o postanowieniu konwokacji, która na prośbę Prusaków zapewniła o utrzymaniu spokoju na granicy. Zaręczali w związku z tym o dołożeniu starań, by ze strony pruskiej nikt nie zakłócał pokoju, i prosili o podobne działania Polaków. Wojewoda płocki w odpowiedzi również zapewnił o chęci utrzymania spokoju, obiecując dopilnowanie tego w ramach swych obowiązków senatorskich ${ }^{35}$. Całkowicie wolny od informacji politycznych jest list wojewody poznańskiego Stanisława Górki (zob. aneks, nr 5). Podejmuje on sprawę zupełnie prywatną. Górka pisał w końcu kwietnia 1587 r. do nadradców, wstawiając się za Konstancją Utmann, żoną mieszczanina nidzickiego, prześladowaną przez niejakiego Jana Salzbergera, określonego przez wojewodę jako człowiek ,impudens et maleferiatus" ${ }^{36}$.

Sam książę pruski Albrecht Fryderyk przysłał do Warszawy poselstwo na czele z Achacym Dohną, przypominając, że jest również senatorem koronnym i domagając się m.in. z tego tytułu prawa do udziału w elekcji. Życzliwej, ale odmownej odpowiedzi na to poselstwo udzielono 8 maja $^{37}$.

Niemniej, choć zarówno księciu pruskiemu osobiście, jak i margrabiemu ansbachskiemu odmówiono prawa do udziału w elekcji, Jerzy Fryderyk wysłał swoje poselstwo do Warszawy na sejm elekcyjny. Wysłannik margrabiego wygłosił przemówienie na sejmie 14 sierpnia, kiedy to słuchano posłów cudzoziemskich. Życzył wyboru dobrego króla, przy czym wprawdzie chwalił obu głównych kandydatów - Zygmunta i Maksymiliana - bardziej jednak skłaniał się ku Habsburgowi. Upominał się także o potwierdzenie praw księstwa, w tym wolności religijnej. Nie zapomniał też apelować o dopuszczenie margrabiego do głosowania na elekcji jako senatora ${ }^{38}$. Odpowiedzi na to poselstwo udzielono 15 sierpnia. Podziękowano za życzliwość dla Polski i pochwały pod adresem arcyksięcia Maksymiliana, ale ponownie odmówiono miejsca w senacie i prawa do głosu na elekcji, przywołując sentencję konwokacji warszawskiej ${ }^{39}$.

${ }^{31}$ A. Vetulani, Lenno pruskie: od traktatu krakowskiego do śmierci księcia Albrechta 1525-1568. Studjum historyczno-prawne, Kraków 1930, s. 123-198; J. Małłek, Prusy Ksiązęce w XVI wieku-panorama lojalności, w: Panorama lojalności. Prusy Królewskie i Prusy Książęce w XVI wieku, red. J. Axer, Warszawa 2001, s. 17.

32 GStA PK, XX HA, OsF 113, k. 183v-185, Senatorzy polscy i litewscy do Jerzego Fryderyka, Warszawa, 7 III 1587 (kopia, brak podpisów).

33 Tamże, k. 186v-189, Protestacja posłów pruskich, Warszawa, 7 III 1587.

${ }^{34}$ Tamże, k. 302-303, Nadradcy pruscy do G. Zielińskiego, K. Niszczyckiego i M. Dulskiego, Królewiec, 7/17 III 1587.

${ }_{35}$ GStA PK, XX HA, HBA B2 407 (kopia: OsF 113, k. 309v-310), G. Zieliński do nadradców pruskich, Wiśniewo, 13 IV 1587.

36 GStA PK, XX HA, HBA B2 407, S. Górka do nadradców pruskich, Poznań, 28 IV 1587.

${ }^{37}$ GStA PK, XX HA, OsF 113, k. 78-79, Senatorzy polscy do Albrechta Fryderyka, Warszawa, 8 V 1587. Brak podpisów pod kopią listu uniemożliwia identyfikację senatorów, którzy odpowiedzieli księciu pruskiemu (zapewne był wśród nich prymas S. Karnkowski).

38 Tamże, k. 364-367v, Przemówienie posła Jerzego Fryderyka na sejmie elekcyjnym, Warszawa, 4 VIII 1587; tamże, k. 368-369, Główne punkty poselstwa odprawionego w Warszawie 14 VIII 1587; Diariusze sejmowe r. 1587, s. 196. R. Heidenstein ocenia, że posłowie pruscy wstawiali się za arcyksięciem „natarczywiej, niż sobie monarcha ich życzył”; tenże, Dzieje Polski, s. 539; zob. A. Pieńkowska, Zjazdy i sejmy, s. 353; A. Barwicka-Makula, Od wrogości do przyjaźni, s. 105.

39 GStA PK, XX HA, OsF 113, k. 370-371, Senat i stany polskie i litewskie do Jerzego Fryderyka, Warszawa, 15 VIII 1587. Na kopii odpowiedzi zaznaczono, że podpisali ją prymas Stanisław Karnkowski, biskup płocki Piotr Dunin Wolski, biskup przemyski i podkanclerzy koronny Wojciech Baranowski, wojewoda krakowski Andrzej Tęczyński, wojewoda sieradzki Olbracht Łaski, wojewoda płocki Grzegorz Zieliński, marszałek wielki koronny Andrzej Opaliński oraz kasztelan chełmiński i podskarbi wielki koronny Jan Dulski. 
22 sierpnia grono senatorów koronnych na czele z prymasem Stanisławem Karnkowskim wysłało do margrabiego Jerzego Fryderyka oficjalne zawiadomienie o dokonanym 19 sierpnia wyborze królewicza Zygmunta Wazy na tron polski (zob. aneks, nr 6). Zarazem zapraszano margrabiego do udziału w koronacji elekta przewidzianej na $18 \times 1587^{40}$. Jak wiadomo, daty tej nie udało się dotrzymać i ostatecznie Zygmunt III został koronowany w katedrze wawelskiej 27 XII $1587^{41}$.

Dodajmy na marginesie, że omawiany list nie jest podpisany, jednakże opatrzono go sześciu pieczęciami, świadczącymi o autentyczności i zarazem o liczbie senatorów. Znajdziemy wśród nich prymasowską Junoszę Stanisława Karnkowskiego, będącego w końcowej fazie elekcji jednym z głównych promotorów kandydatury wazowskiej ${ }^{42}$. Na podstawie innych herbów możemy zidentyfikować dodatkowo dwóch biskupów (Wojciecha Baranowskiego i Wawrzyńca Goślickiego ${ }^{43}$ ) oraz senatorów świeckich: Olbrachta Łaskiego ${ }^{44}$, Stanisława Radzimińskiego ${ }^{45}$ i Jana Dulskiego ${ }^{46}$. Nie ma oczywiście herbu Jelita, którym pieczętował się kanclerz i hetman wielki koronny Jan Zamoyski, wówczas jeszcze unikający jednoznacznego opowiedzenia się za królewiczem szwedzkim.

Król elekt dopiero 7 października stanął na polskiej ziemi, odwiedzając opactwo cystersów w Oliwie, gdzie zaprzysiągł pacta conventa. Następnego dnia stanął w Gdańsku ${ }^{47}$. Wśród ministrów witających nowego króla był podkanclerzy koronny i biskup przemyski Wojciech Baranowski. Odebrał on w Gdańsku wiadomości z Prus Książęcych, zreferowane mu przez Michaela Giesego, za co dziękował nadradcom osobnym listem z 14 X 1587 (zob. aneks, nr 7) ${ }^{48}$. Mamy zatem poświadczone utrzymywanie kontaktów między władzami pruskimi a otoczeniem nowego króla polskiego, jakkolwiek nie znamy szczegółów misji zleconej Giesemu. Niewątpliwie szło jednak o sprawę uznania Zygmunta Wazy za króla polskiego, co poznajemy z treści jego własnych listów wysyłanych w tymże czasie do nadradców ${ }^{49}$.

Ostatnim wreszcie listem, na jaki zwrócimy uwagę, jest odpowiedź kasztelana gdańskiego Macieja Żalińskiego na list margrabiego Jerzego Fryderyka, datowany z Ansbachu 16 X 1587. Kasztelan zawiadamiał o powitaniu wraz z gronem innych senatorów nowego króla Polski. Dzielił się z margrabią zarówno swoimi nadziejami, jak i obawami związanymi z toczącą się już walką o tron (zob. aneks, $\mathrm{nr} 8)^{50}$.

Jak zatem widać, wśród tematyki analizowanych listów polskich senatorów znajdujemy zarówno sprawy polityczne najwyższej wagi - jak zawiadomienie o śmierci monarchy i wyniku elekcji - jak i kwestie prywatne, czasami zgoła błahe. Nie zawsze jesteśmy w stanie wywnioskować, jaką dokładnie materię omawiano, gdy w listach mamy jedynie informację o ustnym zreferowaniu problemu (przykładowo tak

40 GStA PK, XX HA, HBA B2 407 (kopia: OsF 113, k. 372), Senatorzy polscy do Jerzego Fryderyka, Warszawa, 22 VIII 1587.

${ }^{41}$ H. Lulewicz, Gniewów o unię ciag dalszy, s. 409 n.; H. Wisner, Zygmunt III Waza, Wrocław 2006, s. 32 n. Wdowa po Stefanie Batorym zabiegała osobno o przychylność margrabiego dla swego siostrzeńca; GStA PK, XX HA, OsF 113, k. 375-376 (kopia), Anna Jagiellonka do Jerzego Fryderyka, Warszawa, 5 IX 1587; GStA PK, XX HA, HBA B1 335, taż do tegoż, Warszawa, 25 XI 1587.

${ }^{42}$ Rolę prymasa podkreśla R. Heidenstein, Dzieje Polski, s. 543; zob. H. Lulewicz, Gniewów o unię ciąg dalszy, s. 385; A. Pieńkowska, Zjazdy i sejmy, s. 370-373.

${ }^{43}$ Wawrzyniec Goślicki, od 1586 r. biskup kamieniecki, następnie chełmski, przemyski i wreszcie (1601) poznański; zob. D. Maniewska, Goślicki Wawrzyniec (ok. 1530-1607), w: PSB, t. 8, s. 379-382.

${ }_{44}$ Olbracht Łaski, od 1565 r. wojewoda sieradzki, zwolennik kandydatury Zygmunta Wazy; zob. R. Żelewski, Easki Olbracht (1536-1605), w: PSB, t. 18, Wrocław 1973, s. 246-250.

${ }^{45}$ Stanisław Radzimiński, kasztelan czerski i z nominacji Zygmunta III w 1588 r. wojewoda podlaski, uznawany za współpracownika królowej Anny Jagiellonki; zob. J. Choińska-Mika, Radzimiński Stanisław (zm. 1591), w: PSB, t. 30, Wrocław 1987, s. 102-104; A. Pieńkowska, Zjazdy i sejmy, s. 148. Rysunek i napis na pieczęci są niewyraźne, jednak przypisanie jej S. Radzimińskiemu wydaje się najbardziej prawdopodobne.

${ }_{46}$ Jan Dulski, od 1580 r. podskarbi wielki koronny; zob. K. Lepszy, Dulski Jan (zm. 1590), w: PSB, t. 5, Kraków 1939-1946, s. 461 n.

$47 \mathrm{~W}$ połowie września król zapowiadał dopiero gdańszczanom swój przyjazd, ci zaś w końcu tego miesiąca informowali marszałka wielkiego koronnego o spodziewanym rychłym przybyciu elekta; AP Gdańsk, sygn. 300,53/41, nr 19, s. 179, Zygmunt III do rady miasta Gdańska, Kolmar, 13 IX 1587; tamże, nr 20, s. 183, rada miasta Gdańska do A. Opalińskiego. Sam elekt oznajmił swój przyjazd biskupowi warmińskiemu; BCzart., rkps IV/351, nr 19, s. 61, Zygmunt III do M. Kromera, Gdańsk, 10 X 1587; zob. też H. Wisner, Zygmunt III Waza, s. 27 n.

48 GStA PK, XX HA, HBA B2 407, W. Baranowski do nadradców pruskich, Gdańsk, 14 X 1587.

49 GStA PK, XX HA, HBA B1 335, Zygmunt III do nadradców pruskich, Gdańsk, 10 X i 13 X 1587.

${ }^{50}$ GStA PK, XX HA, HBA B2 407, M. Żaliński do Jerzego Fryderyka, Tuchola, 1 I 1588. 
jest w listach Jana Zamoyskiego z grudnia 1586 r. i Wojciecha Baranowskiego z października 1587 r.). W tematyce listów - nawet tych poruszających raczej prywatne sprawy - dominuje wszakże sprawa bezpieczeństwa publicznego bądź nawet osobistego (zob. listy wojewodów płockiego i poznańskiego). Jest to zatem pewien rys szczególny okresu bezkrólewia.

Oczywiście nie mamy do czynienia z zalewem korespondencji - jakkolwiek dalsza kwerenda, także w archiwach polskich, może ujawnić nowe listy ${ }^{51}$. Sytuacja zmieni się w XVII w., gdy wraz ze wzrostem znaczenia władających Prusami elektorów brandenburskich oraz wygaśnięciem polskiej linii Wazów aktywność polityczna Hohenzollernów zintensyfikuje się i zaowocuje wysuwaniem własnych kandydatur na polu elekcyjnym ${ }^{52}$. W ślad za tym zwiększy się liczba listów wymienianych między polskimi dygnitarzami a władzami pruskimi.

\begin{abstract}
Aneks
Edycję przygotowano według zasad opracowanych przez Kazimierza Lepszego w Instrukcji wydawniczej dla źródet historycznych od XVI do połowy XIX wieku, Wrocław 1953. Wszystkie listy wydawane są na podstawie oryginałów przechowywanych w berlińskim Geheimes Staatsarchiv Preußischer Kulturbesitz, w zespole Herzogliches Briefarchiv B2, Kasten 407. Listy napisane są po łacinie, z reguły przez sekretarzy, i najczęściej opatrzone własnoręcznymi podpisami autorów. Odstępując od ścisłych wytycznych Instrukcji, uzgodniono w edycji pisownię „, skowej bądź samogłoskowej. Zachowano oryginalną pisownię małych i wielkich liter, również odstępując w tym od Instrukcji K. Lepszego. Skróty rozwiązano. Odmianki tekstowe pomiędzy oryginałami a kopiami, a także zmiany w tekście oraz fragmenty pisane własnoręcznie przez nadawców listów zaznaczono przypisami tekstowymi. Autor składa podziękowania dr hab. Marcie Przyszychowskiej za pomoc językową w pracy z tekstami łacińskimi.
\end{abstract}

1

Bełz, 17 XII 1586

\title{
Jan Zamoyski do nadradców pruskich
}

Oryg.: GStA PK, XX HA, HBA B2 407 (kopia: OsF 113, k. 49v-50). Na odwrociu odcisk pieczętny $i$ adnotacja $w$ j. niemieckim o otrzymaniu listu w Królewcu 5/15 I 1587 i jego treści. List pisany przez sekretarza, opatrzony własnoręcznym podpisem Jana Zamoyskiego.

Adres: Magnificis ac generosis dominis Illustrissimi Ducis in Prussia etc. etc. ad gubernationem Ducatus Prussiae relictis consiliariis, dominis amicis observandis.

Magnifici et generosi domini, domini amici observandissimi.

De obitu Regiae Maiestatis, principis olim nostri clementissimi, non minus inexspectato ${ }^{a}$ quam tristi quin, cum hae literae Dominationibus Vestris reddentur, iam cognoverint, dubitare mihi non debere

${ }^{51}$ Badanie stosunków polsko-pruskich z okresu trzeciego bezkrólewia wymagałoby przejrzenia w samym Berlinie zespołów zawierających - oprócz listów z Polakami - przeważnie korespondencję wewnątrzpruską, m.in. GStA PK, I HA, Rep. 6/7 (dot. poselstw do Polski w latach 1587-1588, w tym fasc. 1 - misja Giesego); GStA PK, I HA, Rep. 9 (Polen), w tym sygn. 1b, B oraz 1b, C; GStA PK, XX HA, OsF, w tym sygn. 111, 112 i 114.

52 Przykładowo elektor Fryderyk Wilhelm podczas bezkrólewia po śmierci króla Michała Korybuta Wiśniowieckiego lansował początkowo swego syna Karola Emila do korony polskiej; B. Wachowiak, A. Kamieński, Dzieje Brandenburgii-Prus, s. 382; B. Szymczak, Fryderyk Wilhelm. Wielki Elektor, Wrocław 2006, s. 154. 
videor. Casus hic est, quemadmodum sua sponte pro prudentia sua rectius Dominationes Vestrae intelligunt, ut res quidem per se dolenda non tam dolorem tamen, quam consilium atque curam reipublicae, quae in non leve discrimen eo adducta videtur, postulet. Cum autem et respublicae ipsae, et privati pro suo loco hac ratione quam rectissime salutem publicam tueantur, si qui eiusdem reipublicae membra sint, rationes consiliaque sua tali tempore quam maxime communicata habeant, mitto hisce de rebus ad Dominationes etiam Vestras magnificas et Generosas generosum dominum Reinoldum Heidensteinium secretarium, qui de praesente rerum statu pluribus cum Dominationibus Vestris per ${ }^{\mathrm{b}}$ easque cum Illustrissimo principe communicet. Ei igitur ut omnibus de rebus, quas meo nomine illis proponet, summam fidem, non secus quam si ipse coram cum iis ${ }^{\mathfrak{c}}$ agerem, adhibeant de iisdemque et ipsae suam sententiam mihi ostendant, et ut ab Illustrissimo principe responsum quam primum habeam, efficiant, rogo. Easque $^{\mathrm{d}}$ quam optime valere cupio. Belza, die XVII ${ }^{\mathrm{a}}$ Mensis Decembris Anno Domini $\mathrm{M}^{\circ} \mathrm{D}^{\circ} \mathrm{LXXXVI}^{\circ}$.

${ }^{\mathrm{e}}$ Magnificarum et generosarum dominationum studiosissimus Joannes Zamoiski Cancellarius et generalis Capitaneus Manu propria

\footnotetext{
a Kopia OsF 113, k. 49v: exspectato.

b Pierwotnie cum - wyraz poprawiono ta sama ręka. Kopia OsF 113, k. 49v: per.

c Kopia OsF 113, k. 50: ipsis.

d $W$ oryg. easque mata litera.

e-e Fragment dopisany własnoręcznie przez Jana Zamoyskiego.
}

2

Grodno, 21 XII 1586

Wojciech Baranowski podkanclerzy i biskup przemyski do nadradców pruskich

Oryg.: GStA PK, XX HA, HBA B2 407 (kopia: OsF 113, k. 2v-3). Na odwrociu odcisk pieczętny i adnotacja $w$ j. niemieckim o otrzymaniu listu w Królewcu 17/27 XII 1586 i jego treści. List pisany przez sekretarza, opatrzony własnoręcznym podpisem Wojciecha Baranowskiego. Pod ta sama sygnatura znajduje się kopia tego listu, sporządzona jedna ręka w kancelarii odbiorcy.

Adres: Magnificis et Generosis ab Illustrissimo Principe Domino, Domino Georgio Friderico Marchione Brandeburgensi ac in Prussia etc. Duce relictis ad gubernationem in Prussia Consiliariis Dominis amicis observandis.

Magnifici et Generosi Domini, amici observandi.

Quod ita ad nuntium obitus Serenissimi Regis nostri Dominationes Vestrae commotae sint et tantopere se de Maiestatis illius salute sollicitas esse ostendant, agnosco in eo spectatum Dominationum Vestrarum Serenissimi Regis bonique publici studium. Est autem ita, ut ad Dominationes Vestras allatum erat. Excessit ex hac vita Rex noster, non eo quidem die, de quo Dominationes Vestrae acceperant, sed postero, id est Duodecimo Decembris post occasum solis ante primam horam noctis, magno nostro dolore, magno non tantum nostrae, sed universae Christianae Reipublicae incommodo. In id enim is Princeps cogitationes omnes et sollicitudines intenderat suas, ut pro Republica Christiana Christiani Principis officia adimpleret. Sed propter nostra proculdubio peccata conatus et cogitationes Maiestatis suae pro communi bono susceptas Deus Optimus Maximus interrupit atque Principem publicam salutem procurantem a laboriosa hac cura ad coelestis Regni tranquillitatem evocavit. Extinxit autem Maiestatem Regiam febris intrinseca syncopalis cum astmate in paroxismo incidente quinto die, postquam ita aegrotare coeperat, ut in Lectulo decumberet, Citius sane quam aut sperabamus, aut nobis expediebat. Atque haec magno animi mei dolore Dominationibus Vestris significo neque plura iam scribo, tum 
propter acerbitatem doloris, tum propter occupationes meas. Cupio Dominationes Vestras bene valere. Datum Grodnae, die 21 mensis Decembris Anno Domini 1586.

${ }^{\mathrm{a} D o m i n a t i o n u m ~ V e s t r a r u m ~ a m i c u s ~ a d ~ o f f i c i a ~ p a r a t u s ~}$

Albertus Baranowski Episcopus et ViceCancellarius ${ }^{\mathrm{a}}$

a-a Fragment dopisany wtasnoręcznie przez Wojciecha Baranowskiego.

\section{3}

Grodno, 12 I 1587

\section{Wojciech Baranowski do nadradców pruskich}

Oryg.: GStA PK, XX HA, HBA B2 407 (kopia: OsF 113, k. 8-8v). Na odwrociu odcisk pieczętny i adnotacja w j. niemieckim o otrzymaniu listu w Królewcu 8/18 I 1587. List pisany przez sekretarza, ta sama ręka co list $n$ r 2, opatrzony własnoręcznym podpisem Wojciecha Baranowskiego.

Adres: Magnificis et Generosis Dominis ab Illustrissimo Principe Domino Georgio Friderico Marchione Brandeburgensi ac in Prussia etc. Duce ad gubernationem relictis Consiliariis amicis observandis.

Magnifici et Generosi Domini, amici observandi.

Cum hic ad 6 Ianuarii senatores Magni Ducatus Lituaniae convenissent atque deliberationibus de Republica aliquot dies transmississent, proposui in eorum consessu et consilio, quae Dominationes Vestrae ad me scripserunt, nimirum ut quemadmodum ad retinendam tranquillitatem securitatemque publicam et licentiam, quae hoc tristi interregno posset erumpere atque vicinitatis iura perturbare, in Ducatu Prussiae coercendam incumbere se Dominationes Vestrae scribunt, ita vicissim et illis curae sit, quo hinc a Magni Ducatus Lituaniae finibus, subditis Ducatus Prussiae intacta et illibata vicinitatis ratio consistat. Grata est Dominis Senatoribus haec Dominationum Vestrarum de tranquillitate harum provinciarum sollicitudo; atque id negotii Magnificis Domino Vilnensi ${ }^{a}$ Castellano $^{1}$ et Capitaneo Samogitiae ${ }^{2}$ communi senatus istius Ducatus auctoritate datum, ut illi, cum vicinas Ducatui habeant Praefecturas, dent operam, ne quid a quoquam e Lituania in finibus Prussiae per vim et iniuriam agatur. Caeterum ad 2 Februarii diem Varsaviam convocati sunt a Reverendissimo Domino Archiepiscopo ${ }^{3}$ tam Magni Ducatus Lituaniae quam Regni Senatores. Faciam itaque cum pro meo in Illustrissimum Principem perpetuo constantique studio, tum pro bono communi, ut id etiam de tranquillitate securitateque tuenda, quod Dominationes Vestrae requirunt, ad illos deferatur. Atque si ad illam diem Illustrissimi Principis Legati Varsoviam venerint comode et de rebus Ducatus Prussiae cum Senatu Regni agent, et Serenissimam Reginam ${ }^{4}$, quae ad illud tempus nusquam Varsovia proficiscetur, invisent, atque coram illius Maiestate hoc contestandi doloris de obitu Serenissimi Regis extremum officium, quod Illustrissimus Princeps praestare cupit, Celsitudinis Suae nomine testari poterunt. Cupio Dominationes Vestras bene feliciterque valere. Grodna, die 12 Ianuarii Anno Domini 1587.

${ }^{b}$ Dominationum Vestrarum benevolus amicus obsequi paratus

Albertus Baranowski Episcopus et ViceCancellarius ${ }^{\mathrm{b}}$

a Wyraz przycięty krawędzią karty.

b-b Fragment dopisany własnoręcznie przez Wojciecha Baranowskiego.

${ }^{1}$ Eustachy (Ostafi) Wołlowicz (zm. 1587), od 1579 r. kasztelan wileński i kanclerz wielki litewski; zob. T. Wasilewski, Testament Ostafiego Wołlowicza, ,Odrodzenie i Reformacja w Polsce”, 7, 1962, s. 165-167. 
${ }^{2}$ Jan Kiszka h. Dąbrowa (zm. 1592), w latach 1579-1589 starosta generalny żmudzki; zob. J. Tazbir, Kiszka Jan, w: PSB, t. 12, Wroctaw 1966-1967, s. 507 n.

${ }_{3}^{3}$ Stanisław Karnkowski h. Junosza (zm. 1603), od 1581 r. arcybiskup gnieźnieński; zob. H. Kowalska, Karnkowski Stanisław, w: PSB, t. 12, s. 77-82.

${ }^{4}$ Anna Jagiellonka (zm. 1596), od 1575 królowa Polski i wielka księżna litewska.

Grzegorz Zieliński do nadradców pruskich

Oryg.: GStA PK, XX HA, HBA B2 407 (kopia: OsF 113, k. 309v-310). Na odwrociu odcisk pieczętny $i$ adnotacja $w j$. niemieckim o treści listu wojewody płockiego. List pisany zapewne przez sekretarza z własnoręcznym dopiskiem Grzegorza Zielińskiego.

Adres: Illustribus ac Magnificis Dominis Ducatus Prussiae Consiliariis, Dominis et amicis colendissimis.

Illustres ac Magnifici Domini.

Salutem et omnia integerrima Dominationibus vestris, a Deo immortali ex animo precor.

Accepi vestras litteras, cum his etiam et alias a Senatorio ordine inclyti Regni Poloniae, quibus hoc unum contenditis, ut pax et tranquilitas inter hoc principatus, qui arctissimo vinculo amoris ac societatis uniti sunt, tute servetur constantissimeque custodiatur. De me quidem hoc policeri ausim: quidquid dignitatis et auctoritatis meae Senatoriae fuerit, queque digna vicinitate videbuntur, in iis partibus me futurum esse, ne possint merito Dominationes vestrae de me conqueri. Quibus me studiaque mea commendo, eas ex animo bene valere cupiens. Wiszniewie, 13 Aprilis Anno 1587.

Dominationibus vestris addictissimus

Gregorius Zielinski a Goszczyska, Pallatinus Plocensis, Zakroczimensis, Młavensis etc. Capitaneus ${ }^{a}$ manu propria ${ }^{\mathrm{a}}$

a-a Własnoręczny dopisek Grzegorza Zielińskiego.

Stanisław Górka do nadradców pruskich

Oryg.: GStA PK, XX HA, HBA B2 407. Na odwrociu odcisk pieczętny i adnotacja $w$ j. niemieckim o otrzymaniu listu 3/13 V 1587 i jego treści. List pisany przez sekretarza z własnoręcznymi dopiskami Stanisława Górki.

Adres: Generosis Nobilibus et Excellentissimis Dominis, Illustrissimi Ducis in Prussia Consiliariis etc., Dominis et amicis plurimum observandis, Singulariterque dilectis.

Generosi, Nobiles, Excellentissimi Domini, Amici observandi et plurimum dilecti.

Salutem et studiorum mutuique amoris commendationem. Posteaquam intellexissem hominem quendam, uti videtur, inquietum et plane improbum, Ioannem Salczbergerum ${ }^{1}$, Constantiae Utmannae ${ }^{2}$, domini 
Utmanni, civis Neydeburgensis ${ }^{3}$ in Prussia, coniugi, cuius fratrem Henricum Girck ${ }^{4}$ in meo famulitio habeo, praeter omnem culpam et meritum negotium facessere et, quod gravissimum est, foeminae innocentis famam turpiter proscindere, non potui non graviter et moleste id ferre. Namque quod ex plurimis fidedignis hominibus cognovi, homo iste impudens et maleferiatus loco gratiae, quam merito ei referre debebat, odio sine ulla causa in eam concepto, plurimis conviciis malitiose et inique confictis eam palam et publice exagitare non veretur. Faciendum itaque mihi putavi, ut pro memorata Constantia apud Generosas et Excellentissimas Dominationes Vestras petitionem meam interponerem. Quapropter a Generosis et Excellentissimis Dominationibus Vestris maiorem in modum peto, ut hominem istum, indignum sane, qui lucem hanc aspiciat, non solum coerceant et silentium illi imponant, verum etiam in eum, uti meretur, animadvertant. Magistratus enim interest famam innocentium, praecipue vero foeminarum, a morsibus eius modi perditissimorum hominum, qualis is est, vindicare. Quod si, uti non dubito, a Generosis et Excellentissimis Dominationibus Vestris impetro, dabo operam, ut Generosae et Excellentissimae Dominationes Vestrae gratum me semper experiantur.

Bene valere Generosas et Excellentissimas Dominationes Vestras ex animo cupio. Posnaniae, die 28 Aprilis 1587.

Generosarum et Excellentissimarum Dominationum Vestrarum

${ }^{a}$ Benevolus amicus ${ }^{\mathrm{a}}$

Stanislaus Comes a Gorka Palatinus Posnaniensis, Buscensis Colensisque etc. Capitaneus

${ }^{\mathrm{b}}$ manu propria ${ }^{\mathrm{b}}$

a-a Własnoręczny dopisek Stanisława Górki.

b-b Wtasnoręczny dopisek Stanisława Górki.

${ }^{1}$ Jan (Johann) Salzberger, osoba bliżej niezidentyfikowana.

${ }^{2}$ Konstancja Utmann, osoba bliżej niezidentyfikowana.

3 Neidenburg, obecnie Nidzica.

${ }^{4}$ Henryk (Heinrich) Girck, osoba bliżej niezidentyfikowana. Jak wynika z treści listu, związany był ze Stanisławem Górka.

6

Warszawa, 22 VIII 1587

Senatorzy polscy do Jerzego Fryderyka

Oryg.: GStA PK, XX HA, HBA B2 407 (kopia: OsF 113, k. 372). Na odwrociu sześć odcisków pieczętnych $w$ dwóch rzędach z pieczęciami senatorów duchownych na górze: 1) Junosza Stanistawa Karnkowskiego, 2) Jastrzębiec Wojciecha Baranowskiego, 3) Grzymała Wawrzyńca Goślickiego, 4) Korab Olbrachta Łaskiego, 5) Brodzic Stanisława Radzimińskiego, 6) Przeginia Jana Dulskiego. Adnotacja o otrzymaniu listu w Królewcu 29 VIII / 8 IX 1587 i jego treści.

Adres: Illustrissimo Principi Domino, Domino Georgio Friderico Dei gratia Marchioni Brandenburgensi, in Prussia, Stetiniae, Pomoeraniae, Cassuborum ac Sclavorum, nec non in Sylesia, Carnoviae etc. Duci, Burgravio Norimbergensi ac Rugiae Principi, Domino observandissimo.

Illustrissime Princeps, Domine amice observandissime.

Cum Reipublicae nostrae Ordinum consensu divinaque voluntate Decima nona mensis huius Serenissimus Princeps Dominus Sigismundus, Serenissimi Principis Domini Ioannis Tertii Suecorum Regis filius, Rex Poloniae Magnusque Lithuaniae Dux electus et renunciatus esset, ad suam Serenitatem in Regnum advocandam Legati primum quidem a nobis sunt designati, tum vero et dies Coronationis suae Serenitatis dicta Cracoviae XVIII ${ }^{\mathrm{a}}$ mensis Octobris $^{\mathrm{b}}$ anni praesentis ${ }^{\mathrm{c}}$. Qua de re Illustritati Vestrae 
significandum litteris hisce nostris putavimus. Quam bene valere cupimus. Datum Varsoviae e Comitiis electionis generalibus die XXII mensis Augusti Anno Domini $\mathrm{M}^{\circ} \mathrm{D}^{\circ} \mathrm{LXXXVII}^{\circ}$.

Illustrati Vestrae amicissimi

Senatus et ordines Regni Poloniae magnique Ducatus Lituaniae

a Nazwa miasta $w$ formie skróconej Crac, nieco rozmyta; nazwa miasta i liczba XVIII zostały dopisane ta sama ręka, ale ciemniejszym atramentem.

b Nazwe miesiaca dopisano w pozostawionym pustym miejscu, ta sama ręka i atramentem co poprzedni dopisek.

c praesentis, zapisane $w$ formie skróconej pntis, dopisano $w$ pozostawionym pustym miejscu, ta sama ręka i atramentem co poprzednie dopiski. Najpewniej wszystkie elementy szczegółowe daty dopisano później.

7

Gdańsk, $14 \times 1587$

Wojciech Baranowski do nadradców pruskich

Oryg.: GStA PK, XX HA, HBA B2 407. Na odwrociu odcisk pieczętny $i$ adnotacja $w j$. niemieckim o otrzymaniu listu w Królewcu 20/30 X 1587 i jego treści. List pisany przez sekretarza, inna ręka niż listy $n$ r 2 i 3, opatrzony wtasnoręcznym podpisem Wojciecha Baranowskiego.

Adres: Magnificis et Generosis Dominis Alberto Baroni a Kitlicz ${ }^{1}$ Supremo Curiae Magistro, Joanni Rauter $^{2}$ Burgrabio, Georgio a Pudewels ${ }^{3}$ Supremo Marschalco, Laevino a Bulow ${ }^{4}$, Friderico Scharff ${ }^{5}$ Iuris Utriusque Doctori, Cancellario Georgio Varnimo ${ }^{6}$ Illustrissimo Principe Domino in Prussia etc. Duce ad gubernationem relictis Consiliariis in Prussia Dominis et amicis observandis.

Magnifici ac Generosi Domini.

Libenter ea cognovi ex Nobili Domino Michaele Gisio, quae ad me nomine Dominationum Vestrarum Magnificarum ac Generosarum de Illustrissimo Domino Duce in Prussia etc. retulit. Quae porro ille ex me vicissim intellexit, cum Dominationibus Vestris Magnificis referet, eius verbis tantum fidei habeant, quantum ego habui. Cupio Dominationes Vestras Magnificas ac Generosas bene valere eisque me diligenter commendo.

Datum Gedani die 14 Octobris Anno Domini 1587.

${ }^{a}$ Magnificarum et Generosarum Dominationum Vestrarum

amicus obsequi paratus

Albertus Baranowski

Episcopus Praemisliensis, ViceCancellarius ${ }^{\mathrm{a}}$

a-a Wtasnoręczny podpis Wojciecha Baranowskiego.

${ }^{1}$ Albrecht baron von Kittlitz, ochmistrz pruski, starosta tapiawski; w 1582 r. brat udziat w poselstwie do Stefana Batorego; zob. J. Petersohn, Fürstenmacht und Ständetum in Preussen während der Regierung Herzog Georg Friedrichs, 1578-1603, Würzburg 1963, s. 81.

2 Johann (Hans) von Rautter (1539-1605), nadburgrabia pruski.

${ }^{3}$ Georg von Podewills (Pudewels, zm. 1605), naczelny marszałek pruski.

${ }^{4}$ Lewin von Bülow (Bulau), poset Jerzego Fryderyka do Polski w $1582 r$

${ }_{5}^{5}$ Friedrich Scharff, kanclerz pruski, doktor obojga praw, związany z królewiecka Albertina; G.Ch. Pisanski, Entwurf der preußischen Litterärgeschichte, Königsberg 1791, s. 176.

${ }^{6}$ Georg Warnim, osoba bliżej niezidentyfikowana. Pojawia się wraz z Friedrichem Scharffem i Johannem Rautterem jako autor listu do kapituly warmińskiej w 1585 r.; GStA PK, XX HA, HBA C 1a, Kasten 506. 


\section{Maciej Żaliński do Jerzego Fryderyka}

Oryg.: GStA PK, XX HA, HBA B2 407. Na odwrociu odcisk pieczętny $i$ adnotacja $w j$. niemieckim o otrzymaniu listu 3/13 I 1588 i jego treści. List pisany przez sekretarza pismem drobnym, z licznymi abrewiacjami. W podpisie fragmenty pisane własnoręcznie przez Macieja Żalińskiego. Po odpieczętowaniu listu przez odbiorce część adresu stata się niewidoczna.

Adres: Illustrissimo ${ }^{\mathrm{a}}$ domino, domino Georgio Friderico ${ }^{\mathrm{b}}$ Dei gratia Marchioni Brandeburgensic ${ }^{\mathrm{c}}$, in Prussia, Stetini, Pomoeraniae ${ }^{\mathrm{d}}$, Cassuborum, Vandalorum ${ }^{\mathrm{e}},{ }^{\mathrm{f}} \mathrm{nec}$ non ${ }^{\mathrm{f}}$ in Silesia, Carnoviae ${ }^{g}$ etc. Duci ${ }^{\mathrm{g}}$, Burgrabio Noribergensi Rugiaeque ${ }^{\mathrm{h}}$ Principi; domino, domino observandissimo.

Illustrissime princeps, domine, domine observandissime.

Post diligentem studiorum ac officiorum meorum commendationem, Annum hunc ineuntem et multos alios sese consequentes prosperos fore Illustrissimae Dominationi Vestrae precor.

Admodum doleo litteras ab Illustrissima Dominatione Vestra tam sero redditas esse. Datae enim sunt olendino XVI octobris, quas ego heri demum vesperi accepi. Conveneramus autem illo tempore, quo scriptae ${ }^{i}$ sunt, multi ex Senatoribus et proceribus Gedanum ad salutandam et excipiendam Sacram maiestatem Regiam, Serenissimi Regis Sueciae filium, Regem per nos nobis electum, ubi per aliquot hebdomadas commorati sumus et quamvis ab omnibus fere perhonorifica illic fiebat mentio Illustrissimae Dominationis Vestrae, erant enim optime persuasi de studio, amore ac fide illius in Regnum, confirmati tamen fuissent magis omnium animi, si aliquid ab Illustrissima Dominatione Vestra audivissent eiusmodi, cuius modo audire licuit. Ego sane pro studio in illam meo, quod debui, alacriter feci et quantum potui, certificando confirmabam animos eorum. Perspecta enim et satis probata, uti etiam ipsa scribit, mihi multo ante fuit fides ista et constans observantia in Regnum istud Illustrissimae Dominationis Vestrae nec, quod sciam, puto aliquos esse, qui aliter de illa sentire aut statuere velint. Faceret tamen commodissime Illustrissima Dominatio Vestra et omnibus optime eam commendaret, si ad compositionem, si quae attentabitur aut curabitur, quantocitius finiendam officium istud suum, quod offert, praestare velit. Est profecto, quod doleamus vehementer: tam discordes animos et diversa studia civium aliquorum nostrorum fuisse, ut in unum principem coire et consentire non potuerint aut noluerint. Unde quanti motus, tumultus, pericula, damna ex utraque parte orta et factae ${ }^{j}$ sunt, vidimus alia ipsi, de aliis non sine magno moerore audivimus; nec ipsam Illustrissimam Dominationem Vestram latere forsan possunt. Perscribi tam facile, nedum sopiri aut resarciri, nequeunt haec omnia, sexcenta sunt enim et ut simpliciter dicatur, infinita. Parti tamen maiori atque adeo omnibus libertatum iura prospicientibus et deffendentibus quam aliquibus nescitur quid praeseferentibus adhaerendum est; reliqua vero praepotenti Deo comittenda, qui, quod aequum et iustum est magis, declarare et pacem tranquillitatemque pristinam prae sua clementia piis omnium votis exoratus restituere dignabitur. Cum his commendo me et servitia mea in gratiam Illustrissimae Dominationis Vestrae. Datum Tucholiae $1^{\text {a }}$ januarii Anno Domini 1588.

Illustrissimae Dominationis Vestrae

servus $^{\mathrm{k}}$

Matias Zalinski, Castellanus Gedanensis, Tucholiensis, Msciboviensis, Przedboriensis etc. Capitaneus ${ }^{1}$ Manu propria'

\footnotetext{
a $W$ oryg. zachowane strissimo.

b $W$ oryg. zachowane derico.

c $W$ oryg. zachowane andeburgensi.

d W oryg. zachowane eraniae.
} 
e $W$ oryg. zachowane Vanda.

f-f $W$ oryg. zachowane non.

$\mathrm{g}-\mathrm{g}$ Uzupetnienie wydawcy.

${ }^{\mathrm{h}}$ W oryg. zachowane giaeque.

W oryg. scribtae.

j Tak w oryg. Właściwie powinno być facta i być może taki byt zamyst pisarza, a ksztalt ostatniej litery może być wynikiem spłynięcia zbyt wielkiej ilości tuszu z pióra.

k Wyraz zapisany własnoręcznie przez Macieja Żalińskiego.

1-1 Fragment zapisany własnoręcznie przez Macieja Żalińskiego.

\section{Letters of the Crown senators to Margrave George Frederick and Prussian councillors-general during the third interregnum (1586-1587)}

Summary: The third interregnum in the Polish-Lithuanian Commonwealth brought about increased activity of the Crown senators in their relations with Ducal Prussia, represented by Margrave George Frederick residing in Ansbach, and Prussian councillors-general operating in Konigsberg. The correspondence from this period, being the mains subject of the present analysis, focused on the problem of securing peace - especially on the borderland - and the confirmation of the rights of the duchy. Another question was the Margrave's attempt to have the real influence on the election by obtaining the right to vote as the senator of the Commonwealth. The Polish-Prussian correspondence reveals the still marginal but increasingly important role of Ducal Prussia in the internal policy of the Polish-Lithuanian Commonwealth.

Nota o autorze: Dariusz Milewski, dr hab., profesor w Katedrze Historii Nowożytnej Instytutu Historii Uniwersytetu Kardynała Stefana Wyszyńskiego w Warszawie. Zajmuje się historią wojskowości staropolskiej i kontaktami Rzeczypospolitej z Kozaczyzną, Osmanami i ich europejskimi lennikami.

Author: Dariusz Milewski, dr hab., employee of the Institute of History at the Cardinal Stefan Wyszyński University in Warsaw; his fields of interest include military history and relations of Poland with Cossacks, Ottomans and their tributary states: Crimean Khanate, Transylvania, Moldavia and Wallachia.

Instytut Historii

Uniwersytet Kardynała Stefana Wyszyńskiego w Warszawie

ul. Kazimierza Wóycickiego 1/3, bud. 23

01-938 Warszawa

e-mail: d.milewski@uksw.edu.pl

\section{Bibliografia}

\section{Źródła drukowane}

Archiwum Jana Zamoyskiego, kanclerza i hetmana wielkiego koronnego, t. 4: 1585-1588, wyd. K. Lepszy, Kraków 1948

Diariusze sejmowe r. 1587. Sejmy konwokacyjny i elekcyjny, wyd. A. Sokołowski, Scriptores Rerum Polonicarum, t. 11, Kraków 1887

Heidenstein R., Dzieje Polski od śmierci Zygmunta Augusta do roku 1594. Ksiag XII, thum. M. Gliszczyński, oprac. J. Byliński, W. Kaczorowski, Opole 2015

Heidenstein R., Pamiętniki wojny moskiewskiej w 6 księgach, tłum. J. Czubek, Warszawa 2017

\section{Opracowania}

Barwicka-Makula A., Od wrogości do przyjaźni. Habsburgowie austriaccy wobec Polski w latach 1587-1592, Katowice 2019

Hartmann S., Das Geheime Staatsarchiv Preußischer Kulturbesitz in Berlin und Archiv der Herzöge in Preußen (Das Herzogliche Briefarchiv und seine Regestierung), „Mrągowskie Studia Humanistyczne”, 6-7, 2004-2005, s. $350-352$ 
Kowalska H., Karnkowski Stanisław, w: PSB, t. 12, Wrocław 1966-1967, s. 77-82

Lepszy K., Górka Stanisław (1538-1592), w: PSB, t. 8, Wrocław 1959-1960, s. 416-421

Lulewicz H., Gniewów o unię ciąg dalszy. Stosunki polsko-litewskie w latach 1569-1588, Warszawa 2002

Małłek J., Prusy Książęce w XVI wieku - panorama lojalności, w: Panorama lojalności. Prusy Królewskie i Prusy

Ksiażęce w XVI wieku, red. J. Axer, Warszawa 2001, s. 16-20

Niesiecki K., Herbarz polski, t. 3, wyd. J.N. Bobrowicz, Lipsk 1839

Pieńkowska A., Zjazdy i sejmy z okresu bezkrólewia po śmierci Stefana Batorego, Pułtusk 2010

Strzelecki A., Baranowski Wojciech (1548-1615), w: PSB, t. 1, Kraków 1935, s. 286-289

Szczuczko W., Żaliński Maciej, w: Słownik biograficzny Pomorza Nadwiślańskiego, t. 4, red. Z. Nowak, Gdańsk 1997, s. 538 n.

Urzędnicy Prus Królewskich XV-XVIII wieku. Spisy, oprac. K. Mikulski, Wrocław 1990

Vetulani A., Lenno pruskie: od traktatu krakowskiego do śmierci księcia Albrechta 1525-1568. Studjum historyczno-prawne, Kraków 1930

Wachowiak B., Kamieński A., Dzieje Brandenburgii-Prus na progu czasów nowożytnych (1500-1701), Poznań 2001

Wasilewski T., Testament Ostafiego Wołłowicza, „Odrodzenie i Reformacja w Polsce”, 7, 1962, s. 165-173

Zieliński R., Wojewoda płocki Grzegorz Zieliński († 1599), „Notatki Płockie”, 2, 1957, nr 6, s. 2-8 